\title{
A Study on Geomorphological Response for Runoff Prediction in Small Watershed
}

\author{
Dr. B.R. Singh ${ }^{*}$, Er. Sweta Singh ${ }^{* *}$, Dr. Papu Singh ${ }^{* * *}$ and Er. D.K. Mishra ${ }^{* * *}$ \\ ${ }^{*}$ Professor \& Ex-HOD. Department of Agricultural Engineering and Food Technology; College of Agriculture; \\ Sardar Vallabhbhai Patel University of Agriculture \& Technology, Meerut-250110, (U.P.) INDIA \\ ${ }^{* *}$ Ph.D. Scholar. Department of Agricultural Engineering and Food Technology; College of Agriculture; \\ Sardar Vallabhbhai Patel University of Agriculture \& Technology, Meerut-250110, (U.P.) INDIA; \\ ${ }^{* * *}$ Researcher. Department of Agricultural Engineering and Food Technology; College of Agriculture; \\ Sardar Vallabhbhai Patel University of Agriculture \& Technology, Meerut-250110, (U.P.) INDIA; \\ ${ }^{* * * *}$ Assistant Professor. Department of Agricultural Engineering and Food Technology; College of Agriculture; \\ Sardar Vallabhbhai Patel University of Agriculture \& Technology, Meerut-250110, (U.P.) INDIA.
}

\begin{abstract}
Hydrological data of Arki sub-watershed comprising an area of 2460 hectares of a hilly catchment of Upper River Gambhar, located in mid hills of Solan district of Himachal Pradesh were analyzed to study the geomorphological response for estimation of direct runoff by using GIUH model. GIUH model was based on storm basis incorporating geomorphological parameters with the hydrological characteristics of the watershed. Geomorphological parameters were derived from topographic maps of the watershed satisfying Horton's ${ }^{1}$ (1945) law when ordered according to Strahler ${ }^{2}$ (1957) ordering procedure. The GIUH of the watershed was calibrated using the observed direct runoff hydrograph data. Direct runoff hydrographs were obtained from GIUH and these were compared with the observed DRHs to judge the performance of the model. The model performed well for all the test data sets with high coefficient of efficiency, lower relative squared error and absolute relative error in computed peak flow rates values and near zero Coefficients of Residual Mass values. The percentage absolute error in time to peak between computed and observed direct runoff hydrograph was found to be zero percent. The performance of the model showed that it simulates components of direct runoff of hydrographs well.
\end{abstract}

Key words: Watershed, Runoff, Instaneous, Unit Hydrograph and Rainfall

\section{Introduction}

Development of rainfall-runoff models for accurate estimation of runoff is very important for proper planning, design and management of water resources projects. As a result of continuous research in the field of hydrological modelling many models have been developed to define the rainfall-runoff relationship of ungauged watersheds. There has been a gap in the coupling of quantitative geomorphological analysis with the most important hydrologic variables namely, the stream flow response to the surface runoff of geomorphological unit. An improvement over some of the models is the geomorphology-based models e.g., Gupta and Waymire ${ }^{3}$ (1983), which represent the watershed structure and the stream network well. The watershed geomorphology plays a major role in the transformation of rainfall into runoff. By using the quantitative geomorphological parameters of a watershed, its hydrological response can be modeled. In the present study this concept has been successfully used for the development of geomorphological parameters and geomorphological instantaneous unit hydrograph (GIUH) for Arki watershed (2460 ha) of hilly catchment of river Gambhar, located in Himachal Pradesh.

\section{Materials and Method}

\section{Study Area}

The Arki watershed, a hilly catchment of river Gambhar lies in mid hills in Solan district of Himachal Pradesh as shown in Fig. 1. The watershed is located between $31^{\circ} 8^{\prime} 58^{\prime \prime}$ to $31^{\circ} 12{ }^{\prime} 58^{\prime \prime} \mathrm{N}$ latitude and $76^{\circ} 56^{\prime} 50^{\prime \prime}$ to $76^{\circ} 59^{\prime} 50^{\prime \prime}$ E longitudes. The watershed has an area of $24.60 \mathrm{sq} \mathrm{km}(2460 \mathrm{ha})$ and the shape of the watershed is more or less rectangular with mean length of $7 \mathrm{~km}$ and width $3.5 \mathrm{~km}$. The maximum elevation of the watershed at its upstream is $1828 \mathrm{~m}$ whereas it is $1060 \mathrm{~m}$ above mean sea level at the gauging station near the Arki town. The watershed has a hilly terrain with extremely undulating and irregular slopes varying from relatively flat in the valleys to quite steep towards ridges. On the basis of prevailing slopes, the land may be classified under three categories, i.e. valley, moderate and steep hills. The average slope of the watershed is about 9 per cent. Agriculture is practiced on narrow width terraces constructed on slopes ranging from 10 per cent to 45 per cent. 


\section{Geomorphological Data}

The drainage map and the contour map of the Arki watershed were obtained from the Divisional Forest office (Hydrology Investigation Division), Shimla, Himachal Pradesh and used to determine the geomorphological parameters. Fig. 2 and 3 shows the stream ordering for the watershed and the area contributing to different order streams, respectively. Geomorphological parameters for the watershed were determined with the

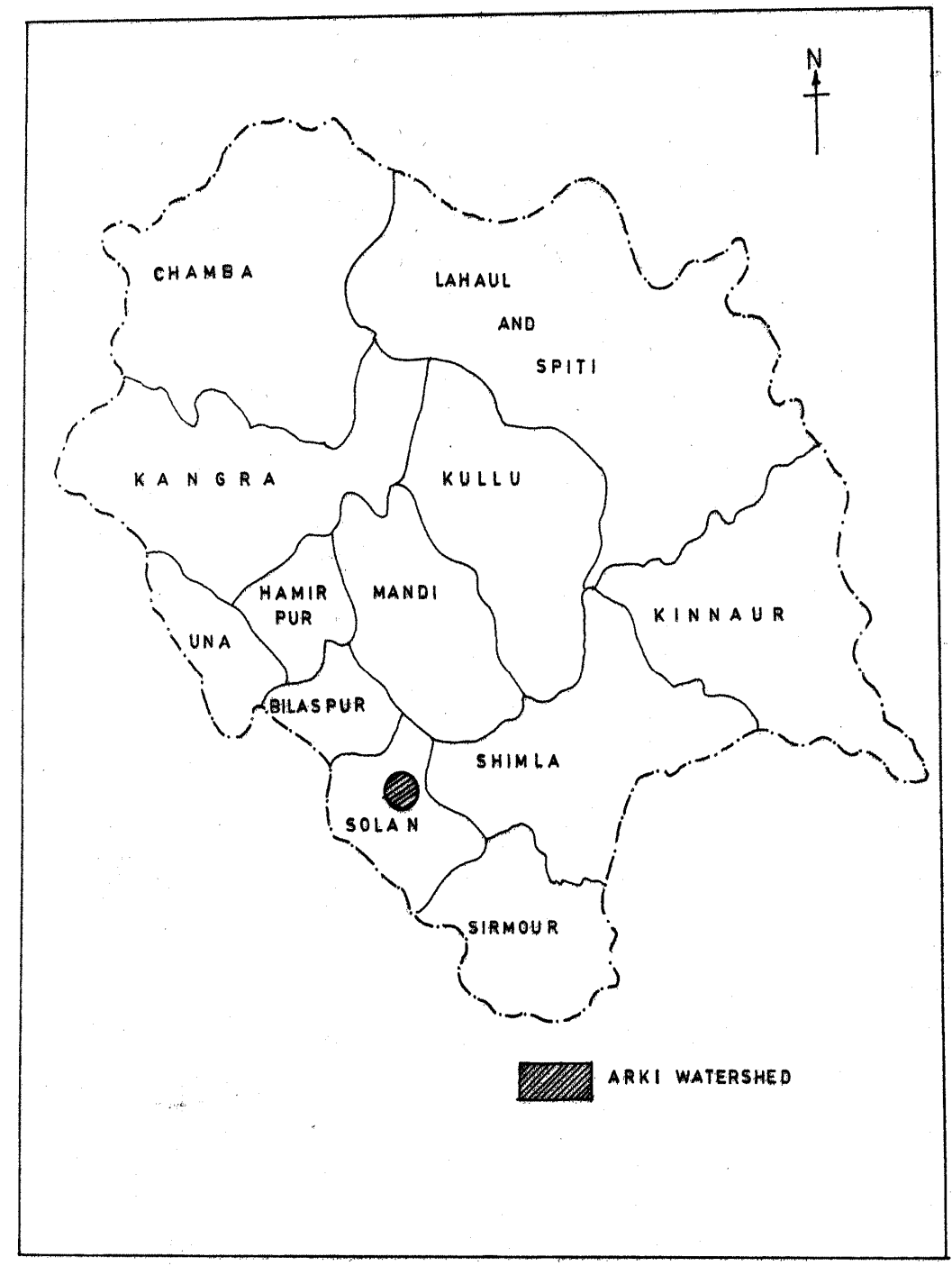

FIG. $\mid$ LOCATION OF ARKI WATERSHED IN HIMANCHAL PRADESH 

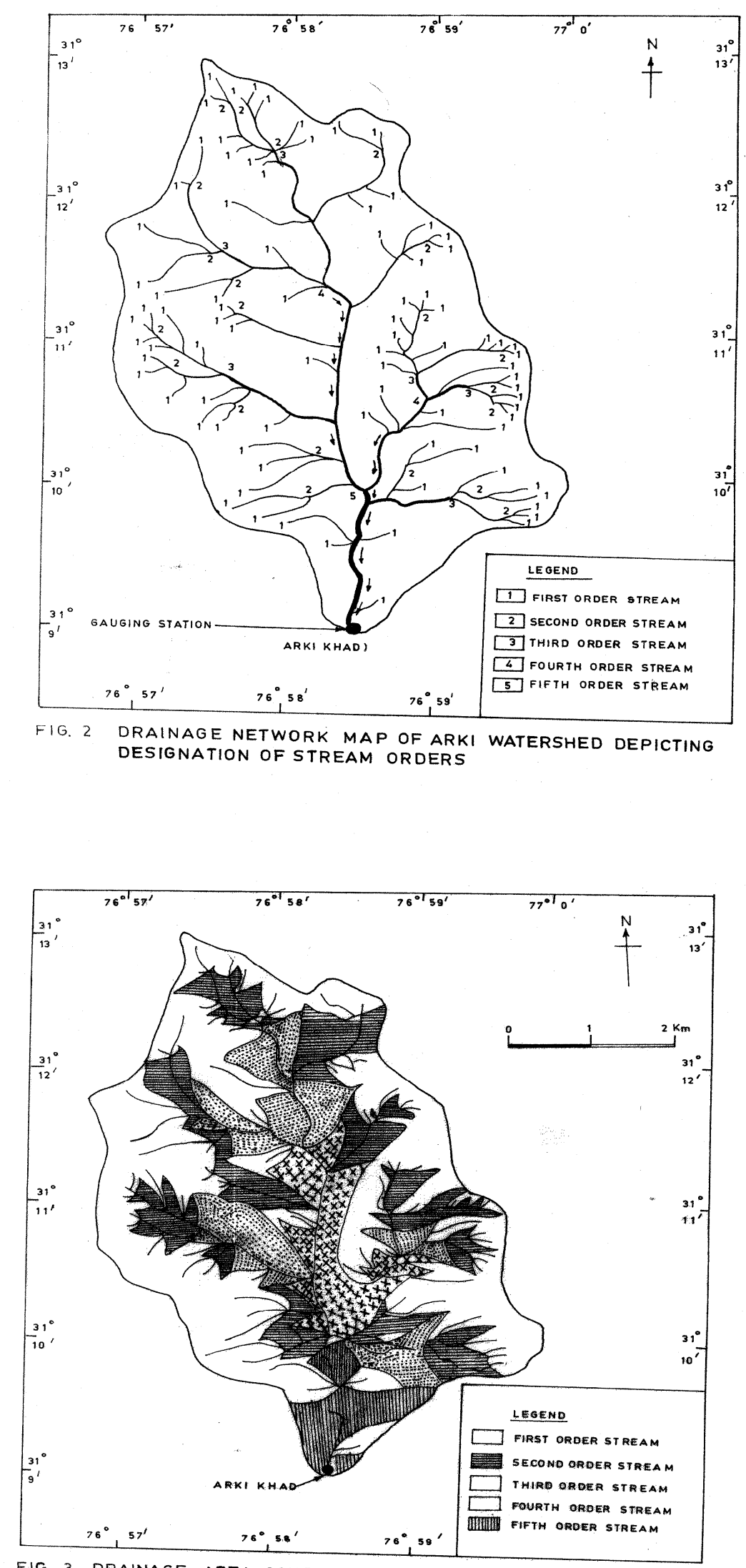

FIG. 3 DRAINAGE AREA CONTRIBUTION MAP OF ARKI WATERSHED 
help of different maps of the study area (Table 1). The geomorphological ratios, i.e. bifurcation ratio, $R_{B}$, area ratio, $R_{A}$, and length ratio, $R_{L}$, were estimated using Horton's (1945) graphical procedure and their values were found as $3.0767,3.6753$ and 1.5774 , respectively.

\section{Rainfall and Runoff data}

The rainfall and runoff data were obtained from Divisional Forest office (Hydrology Investigation Division), Shimala, Himachal Pradesh. The rainfall data were collected with the computerized automatic rain gauge (Tipping bucket type automatic rain gauge) and runoff in the form of stage hydrograph is being measured by data logger connected to the automatic water level recorder installed at the gauging station in the watershed. The collected rainfall and runoff data were used for determining the Geomorphological Instantaneous Unit Hydrographs for the study area.

\section{Geomorphological Instantaneous Unit Hydrograph (GIUH) Model}

The Geomorphological Instantaneous Unit Hydrograph (GIUH) Model used in the present study is based on the theory proposed by Rodriguez-Iturbe \& Valdes ${ }^{4}$ (1979) and its subsequent generalization by Gupta $^{5}$ et al. (1980). According to the theory, the unit input (unit depth of rainfall) is considered to be composed of an infinite number of small, non-interacting drops of uniform size, falling instantaneously over the entire region. The travel time of a randomly chosen drop of water, from its starting point to the outlet, represents the instantaneous unit hydrograph (IUH) of the basin. The Instantaneous Unit Hydrograph for the Arki watershed was developed by the convolution of the probability density function of travel time with the help of geomorphological characteristics of the watershed, and is finally expressed as:

$$
\mathrm{h}(\mathrm{t})=\sum_{\mathrm{s} \in \mathrm{S}} \sum_{\mathrm{j}=1}^{\mathrm{k}} \mathrm{C}_{\mathrm{jk}} \exp \left(-\lambda_{\mathrm{X}_{\mathrm{j}}} \mathrm{t}\right) \mathrm{p}(\mathrm{s})
$$

Where, $p(s)$ is the probability that a drop follows a particular path $\mathrm{S}_{\mathrm{K}}$ from a finite set of possible paths to reach the outlet and is given by:

$$
\mathrm{p}(\mathrm{s})=\pi_{\mathrm{r}_{1}} \mathrm{p}_{\mathrm{x}_{1} \mathrm{x}_{2}} \cdots \cdots \cdots \cdots \mathrm{p}_{\mathrm{x} k-1^{\mathrm{x}} \mathrm{k}}
$$

where, is the initial state probability, defined as the ratio of the total area of the overland segment draining directly to stream of order $i$ to the total watersheds area; and $\mathrm{P}_{\mathrm{ij}}$ is the transition probability, defined as the ratio of the number of streams of order $i$ draining to stream of order $j$ to total number of streams of order $j$. The possible path space for the study area, i.e., for $5^{\text {th }}$ order watershed, is given as:

$\mathrm{S}=\left\{\mathrm{S}_{1}, \mathrm{~S}_{2}, \mathrm{~S}_{3}, \mathrm{~S}_{4}, \mathrm{~S}_{5}, \mathrm{~S}_{6}, \mathrm{~S}_{7}, \mathrm{~S}_{8}, \mathrm{~S}_{9}, \mathrm{~S}_{10}, \mathrm{~S}_{11}, \mathrm{~S}_{12}, \mathrm{~S}_{13}, \mathrm{~S}_{14}, \mathrm{~S}_{15}, \mathrm{~S}_{16}\right\}$

These paths are the combination of overland $\left(\mathrm{r}_{\mathrm{j}}\right)$ and channel flow $\left(\mathrm{c}_{\mathrm{j}}\right)$ states and are expressed as follows:

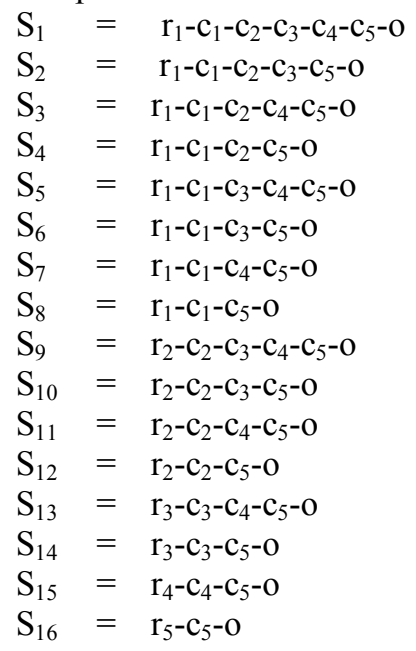

$\mathrm{C}_{\mathrm{jk}}$ in equation (3) is expressed as:

$C_{j k}=\frac{\lambda_{x_{1}} \cdot \lambda_{x_{2}} \cdot \ldots \lambda_{x_{k}}}{\left(\lambda_{x_{1}}-\lambda_{x_{j}}\right) \cdot\left(\lambda_{x_{2}}-\lambda_{x_{j}}\right) \cdot \ldots\left(\lambda_{x_{j-1}}-\lambda_{x_{j}}\right) \cdot\left(\lambda_{x_{j+1}}-\lambda_{x_{j}}\right) \cdot \ldots\left(\lambda_{x_{k}}-\lambda_{x_{j}}\right)}$

Where, $\lambda_{\mathrm{x}_{\mathrm{j}}}$ is the parameter termed as mean holding time of a drop. 
The values of parameter $\lambda_{\mathrm{x}_{\mathrm{j}}}$ are not directly obtainable. However, for overland and channel flow states, these can be determined as:

$$
\begin{aligned}
& \frac{1}{\lambda_{\mathrm{r}_{\mathrm{i}}}}=\gamma\left[\frac{\pi_{\mathrm{r}_{\mathrm{i}}} \mathrm{A}_{\Omega}}{2 \mathrm{~N}_{\mathrm{i}} \overline{\mathrm{L}_{\mathrm{i}}}}\right]^{1 / 3} \quad 1 \leq \mathrm{i} \leq \Omega \\
& \text { and } \\
& \frac{1}{\lambda_{\mathrm{c}_{\mathrm{i}}}}=\gamma \overline{\mathrm{L}}_{\mathrm{i}}^{-1 / 3} \quad 1 \leq \mathrm{i} \leq \Omega
\end{aligned}
$$

\begin{tabular}{|c|c|c|c|c|c|c|}
\hline \multicolumn{6}{|c|}{ Order of the basin } & \multirow[b]{2}{*}{$\begin{array}{l}5 \\
\text { Area of } \\
\text { draining } \\
\text { directly to } \\
\text { streams, A'i } \\
(\mathrm{km} 2)\end{array}$} \\
\hline $\begin{array}{l}\text { Stream } \\
\text { order, } \mathrm{i}\end{array}$ & $\begin{array}{l}\text { Total number } \\
\text { streams, Ni }\end{array}$ & $\begin{array}{l}\text { of Total length of } \\
\text { streams, Li }\end{array}$ & $\begin{array}{l}\text { Mean stream length, } \\
\mathrm{Li} \\
(\mathrm{km})\end{array}$ & $\begin{array}{l}\text { Total area of } \\
\text { streams, } \mathrm{Ai}\end{array}$ & $\begin{array}{l}\text { Mean stream area, Ai } \\
(\mathrm{km} 2)\end{array}$ & \\
\hline 1 & 85 & 42.9250 & 0.5050 & 11.3050 & 0.1330 & 11.3050 \\
\hline 2 & 21 & 17.6610 & 0.8410 & 18.5640 & 0.8840 & 7.2590 \\
\hline 3 & 6 & 9.5400 & 1.5900 & 21.4200 & 3.5700 & 2.8560 \\
\hline 4 & 2 & 7.1600 & 3.5800 & 23.2400 & 11.6200 & 1.8200 \\
\hline 5 & 1 & 2.3900 & 2.3900 & 24.6000 & 24.6000 & 1.3600 \\
\hline
\end{tabular}

Table 1. Geomorphological parameters of the Arki Watershed

\begin{tabular}{lllll} 
No. of streams draining directly to streams of higher order & & & \\
\hline Order & 2 & 3 & 4 & 5 \\
\hline 1 & 68 & 7 & 6 & 4 \\
2 & - & 17 & 4 & 1 \\
3 & - & - & 5 & 2 \\
4 & - & - & - & 3.0767 \\
\hline Bifurcation ratio (RB) & & & 1.5774 \\
\hline Length ratio (RL) & & 3.6753 \\
\hline Area ratio (RA)
\end{tabular}

where, $\Omega$ is the order of the watershed; $N_{j}$, number of stream of order $j ; \bar{L}_{j}$, mean length of stream of order $j$; and $\gamma$ is the empirical constant, ie, the mean holding time of a give state. $\lambda_{\mathrm{r}_{\mathrm{i}}}, \lambda_{\mathrm{c}_{\mathrm{i}}}$ are the parameters for overland and channel flow state.

The mean holding time is obtained from the direct runoff hydrograph of the watershed by equating the first moment of the IUH with that of the DRH. $C_{j k}$ is calculated using equation (5) whereas, $\lambda_{x_{j}}\left(x_{j} \in\left\{r_{j}, c_{j}\right)\right.$ is calculated using equations (6) and (7) for overland and channel flow states, respectively. By substituting the values of $\lambda_{x_{j}}$ in equation (5), the values of $C_{j k}$ can be obtained. After substituting the values of $C_{j k}, \lambda_{x_{j}}$ and $p(s)$ in equation (1), the GIUH ordinates for the watershed were obtained. Which are illustrated in Fig. 4.

\section{Estimation of parameters of GIUH model}

The required parameters, initial state probabilities, transitional probabilities and path probabilities were estimated by using appropriate method as described by $\operatorname{Singh}^{6}$ et al. (2000). By using the observed DRH and the estimated net effective rainfall intensity, the mean holding time of the watershed was estimated. From these parameters the coefficients of the final equation (1) were estimated (Table 2).

\section{Computation of Direct Runoff Hydrograph}

The ordinates of direct runoff hydrograph for the watershed were obtained using the derived GIUH by convoluting the effective rainfall hyetograph with the GIUH. The ordinates of direct runoff hydrograph, $Q(t)$ at any time t may be given as: 
$\mathrm{Q}(\mathrm{t})=\int_{0}^{\mathrm{t}^{\prime}} \mathrm{u}(\mathrm{t}-\tau) I(\tau) \mathrm{d} \tau$

Where, $\mathrm{u}(\mathrm{t})$ is IUH ordinate; and $I(\tau)=$ effective rainfall of duration $\mathrm{t}_{0}$

$\mathrm{t}^{\prime}=\mathrm{t}$ when $\mathrm{t}<\mathrm{t}_{0}$

$\mathrm{t}^{\prime}=\mathrm{t}_{0}$ when $\mathrm{t} \geq \mathrm{t}_{0}$

Table 2. Estimated values of model parameters for GIUH of the Arki Watershed

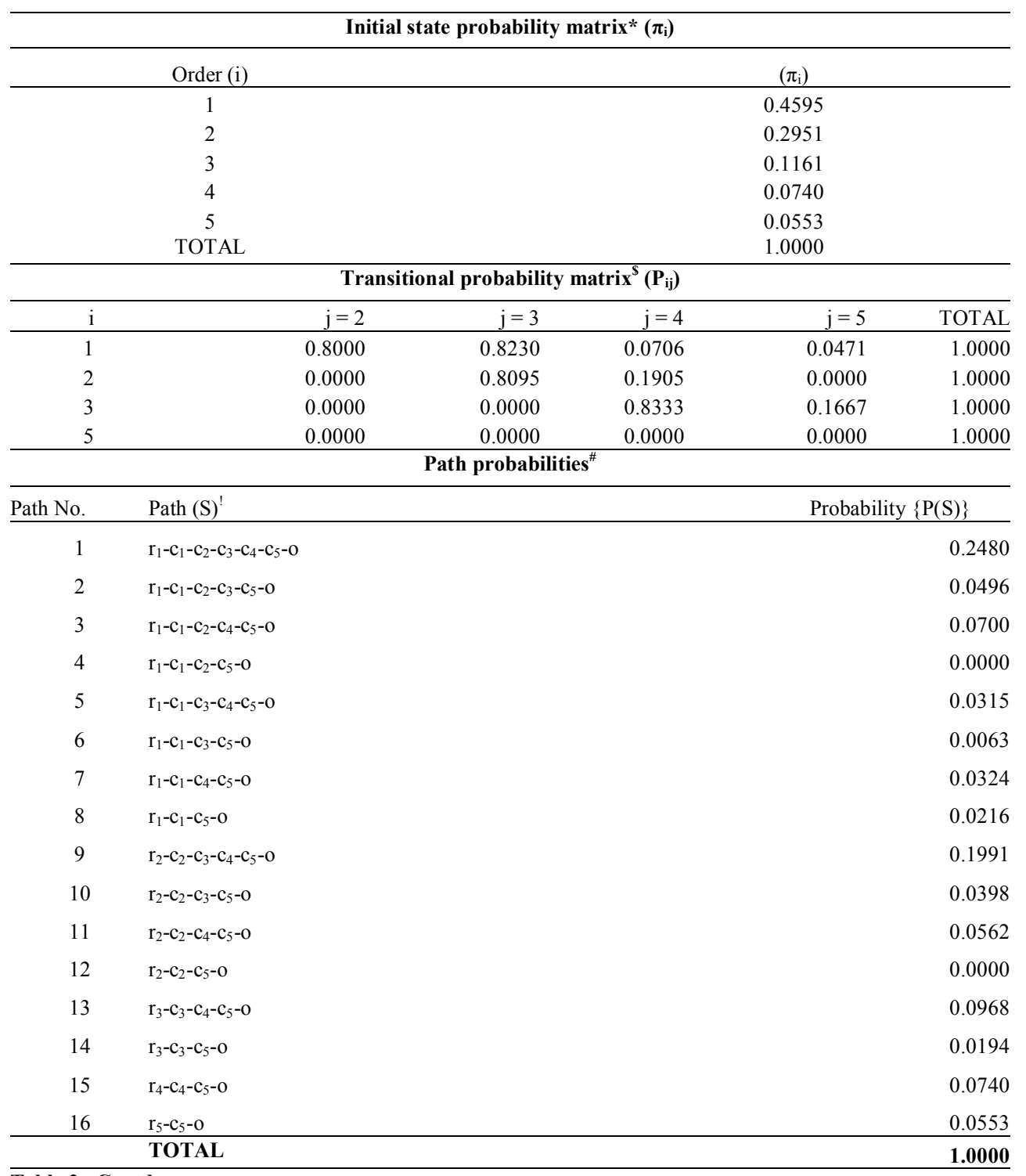

Table 2. Contd....

$\mathrm{K}_{\mathrm{B}}=1.9043$ and $\mathrm{Gamma}=0.3876$

\begin{tabular}{lcc}
\hline & Lambda valuses \\
\hline $\mathrm{i}$ & $\ldots \ldots \boldsymbol{\lambda}_{\mathrm{ri}}$ and $\boldsymbol{\lambda}_{\mathrm{ci}}$ values & \\
\hline 1 & $\lambda_{\mathrm{ri}}$ & $\lambda_{\mathrm{ci}}$ \\
2 & 5.0717 & 3.2402 \\
3 & 4.3724 & 2.7336 \\
4 & 4.8596 & 2.2107 \\
5 & 5.1320 & 1.6867 \\
\hline & 3.9231 & 1.9299 \\
\hline
\end{tabular}




\begin{tabular}{|c|c|c|c|c|c|c|}
\hline Path No.(i) & $\mathbf{j}=\mathbf{0}$ & $\mathbf{j}=\mathbf{1}$ & $\mathbf{j}=\mathbf{2}$ & $\mathbf{j}=\mathbf{3}$ & $\mathrm{j}=4$ & $\mathbf{j}=\mathbf{5}$ \\
\hline 1 & -2.4809 & 166.2694 & -620.3647 & 1426.4389 & 460.7851 & -1430.6478 \\
\hline 2 & 4.9789 & -153.1364 & 385.0443 & -443.1602 & 206.2734 & \\
\hline 3 & 3.2107 & -77.4261 & 146.7273 & 109.2221 & -181.7340 & \\
\hline 4 & -6.4434 & 71.3105 & -91.0698 & 26.2027 & & \\
\hline 5 & 2.1220 & -30.8127 & 272.8454 & 176.4681 & -420.6228 & \\
\hline 6 & -4.2586 & 28.3789 & -84.7665 & 60.6462 & & \\
\hline 7 & -2.7462 & 14.3485 & 41.8291 & -53.4314 & & \\
\hline 8 & 5.5113 & -13.2151 & 7.7038 & & & \\
\hline 9 & 3.7011 & -119.2976 & 517.1094 & 240.0498 & -641.5627 & \\
\hline 10 & -5.8932 & 74.0449 & -160.6534 & 92.5017 & & \\
\hline 11 & -3.6190 & 28.2160 & 56.9002 & -81.4972 & & \\
\hline 12 & 5.7625 & -17.5129 & 11.7504 & & & \\
\hline 13 & -1.4202 & 89.7126 & 86.4867 & -174.7791 & & \\
\hline 14 & 2.6716 & -27.8716 & 25.2000 & & & \\
\hline 15 & 1.5142 & 19.9379 & -21.4521 & & & \\
\hline 16 & -3.7985 & 3.7985 & & & & \\
\hline
\end{tabular}

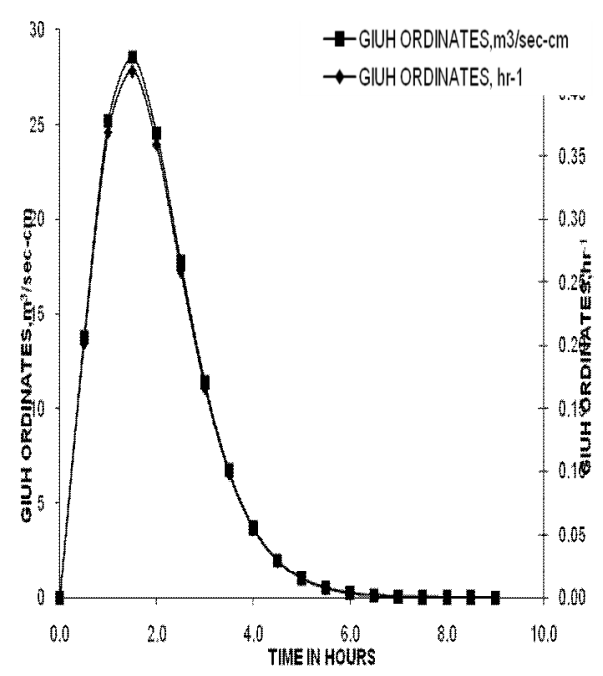

Fig. 4. Geomorphological Instantaneous Unit Hydrograph for Arki Watershed by using GIUH Model.

Above integral is known as convolution integral and is difficult to solve, so an approximate numerical method is adopted to solve the integral as follows.

$Q(\mathrm{t})=\sum_{\mathrm{i}=1}^{\mathrm{M}} Q_{i}=\sum_{\mathrm{i}=1}^{\mathrm{M}} I_{i}(t) \mathrm{u}(\mathrm{t}-(\mathrm{i}-1) \mathrm{D})$

Where, $I_{i}(t)$ is the rainfall excess value at $i^{\text {th }}$ part, when total time $t$ is divided into $M$ equal parts of $D$ duration.

By utilizing equation (9), the direct runoff hydrographs were estimated for Arki watershed.

\section{Results And Discussion}

The primary goal of the developing geomorphological instantaneous unit hydrographs of the watershed was to apply these for hydrograph generation and prediction which may be used in water resources planning. The ordinates of GIUH for Arki watershed were computed by the equations (1) which are shown in Fig. 4. As a test, to verify and validate the equivalence between computed and observed direct runoff hydrographs, the qualitative relative performance of the model developed in the study was examined by visual comparisons of various components of the regenerated and predicted direct runoff hydrographs with respect to the observed direct runoff hydrographs of the corresponding storm events. The quantitatively performance of the model as regards to regeneration and prediction of storm runoff hydrographs was compared with one another by determining statistical measures, namely, coefficient of efficiency, relative squared error, absolute relative error in computed peak flow rates and coefficient of residual mass (Table 3).

The regenerated direct runoff hydrograph for the representative storm event of July 8, 1994 and the predicted direct run off hydrograph for the representative storm event of July 20, 1994 are illustrated in Fig. 5 and Fig. 6, respectively for comparison with the observed direct runoff hydrographs of the corresponding storm 
event. On the basis of the qualitative and quantitative performance of the GIUH model with regards to regenerating and predicting of the direct runoff hydrographs, it is

Table 3. Estimated values of coefficient of efficiency, relative squared error, absolute relative error in computed peak flow rates and coefficient of residual mass on storm basis for Arki watershed

\begin{tabular}{l|c|c|cc}
\hline Date of storm event & $\begin{array}{c}\text { Coefficient of } \\
\text { efficiency, E }\end{array}$ & $\begin{array}{c}\text { Relative } \\
\text { squared error, } \\
\text { RSE }\end{array}$ & $\begin{array}{c}\text { Absolute relative error } \\
\text { in computed peak flow } \\
\text { rates (\%), E }\end{array}$ & $\begin{array}{c}\text { coefficient of residual } \\
\text { mass, CRM }\end{array}$ \\
\hline August 6, 1993 & 0.8392 & 0.0746 & 0.0000 & +0.0131 \\
July 8, 1994 & 0.9949 & 0.0031 & 4.0284 & +0.0086 \\
August 2-3, 1994 & 0.9376 & 0.0334 & 0.4598 & +0.0081 \\
August 23, 1994 & 0.9446 & 0.0363 & 2.7273 & +0.0311 \\
September 5, 1994 & 0.9736 & 0.0149 & 0.1653 & +0.0052 \\
September 8, 1994 & 0.9781 & 0.0129 & 2.9126 & +0.0099 \\
June 30, 1996 & 0.9622 & 0.0195 & 7.5652 & +0.0079 \\
August 2-3, 1996 & 0.9772 & 0.0126 & 4.3290 & +0.0107 \\
September 2, 1996 & 0.9442 & 0.0310 & 2.4000 & +0.0056 \\
August 12, 1997 & 0.9459 & 0.0298 & 3.9370 & +0.0055 \\
\hline Average value & 0.9498 & 0.0268 & 2.8525 & +0.0106 \\
\hline February 2,1994* & 0.9498 & 0.0286 & 7.6158 & +0.0082 \\
February 20,1994* & 0.9546 & 0.0245 & 0.3384 & +0.0057 \\
July 19,1994* & 0.9446 & 0.0255 & 3.6427 & +0.0079 \\
July 20,1994* & 0.9712 & 0.0151 & 1.5957 & +0.0078 \\
\hline Average value & 0.9550 & 0.0234 & 3.2982 & +0.0074 \\
Overall Average value & 0.9513 & 0.0258 & 2.9798 & +0.0097 \\
\hline Predicted sto & \\
\hline
\end{tabular}

*Predicted storm events.

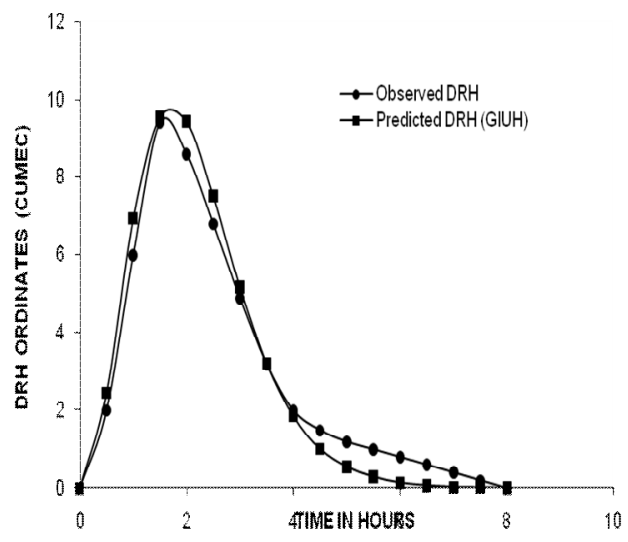

Fig. 5. Comparison of Observed and Regenerated Direct

Runoff Hydrographs for the Storm Event of July 8, 1994 for Arki Watershed 


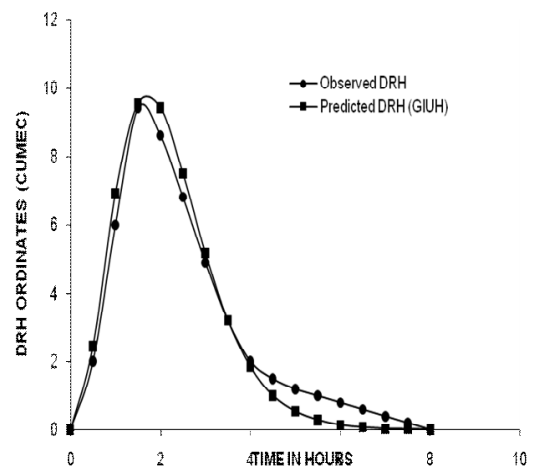

Fig. 6 Comparison of Observed and Predicted Direct Runoff Hydrographs for the Storm Event of July 20, 1994 for Arki Watershed

Concluded that GIUH model simulates well with closer agreement with the observed direct runoff hydrographs.

\section{Conclusion}

Based on the overall qualitative, quantitative performance of the model, the GIUH model can very well be used for regeneration and prediction of direct runoff hydrographs with sufficient degree of accuracy.

\section{Acknowledgements}

The authors are grateful to Divisional Forest office (Hydrology Investigation Division) Shimala, Himachal Pradesh for providing the data used in the investigations. The authors are thankful to the G.B. Pant University of Agriculture and Technology, Pantnagar-263 145, U.S. Nagar, Uttaranchal (India) for providing the facilities during the investigations.

\section{References}

[1]. Horton, R.E. 1945. Erosional development of streams and their drainage basins: hydrological approach to quantitative morphology. Bulletin Geological Society of America, 56:275-370.

[2]. Strahler, A.N. 1957. Quantitative analysis of watershed geomorphology. Transactions of the American Geophysical Union, 38 : 913-920.

[3]. Gupta, V.K. and Waymire, E. 1983. On the formulation of an analytical approach to hydrologic response and similarity at basin scale. Journal of Hydrology, 65:95-123.

[4]. Rodriguez-Iturbe, I. and Valdes, J.B. 1979. The geomorphologic structure of hydrologic response. Water Resource Research, 15 (6):1409-1420.

[5]. Gupta, V.K., Waymire, E. and Wang, C.T. 1980. A representation of an instantaneous unit hydrograph from geomorphology. Water Resources Research, 16 (5):855-862.

[6]. Singh, M.K., Panigrahy, N. and Singh, R. 2000. Development, calibration and validation of Geomorphological Instantaneous Unit Hydrograph (GIUH) model for small watershed. IE (I) Journal of the Institution of Engineers (India), 80: 27-34.

[7]. Singh, B.R., Kumar, V. and Singh, S.K. 2004. "Development of a Geomorphological Instantaneous Unit Hydrogroph (GIUH) for mandapa watershed"-Lead technical paper, proceeding of the National symposium of "second generation problem in Agriculture and its remedies" held at S.V.P.U.A\&T, Meerut U.P. during 26-27 November ,2004, pp 162-170. 